Paper ID \#19020

\title{
Teaching and Learning through Stories: A Preliminary Study
}

\section{Prof. Orla LoPiccolo M. Arch, PDip (CM), Architect, State University of New York, Farmingdale}

Orla Smyth LoPiccolo is a registered architect who joined the faculty of the Department of Architecture and Construction Management in September 2008. Prior to joining Farmingdale State College, Professor LoPiccolo was an adjunct professor for the Department of Architecture and Design, New York Institute of Technology for 5 years, where she taught a variety of design studio classes. Professor LoPiccolo has private sector architecture and project management experience in both Dublin, Ireland and on Long Island, NY, and she has over 10 years of public sector experience as an architect and a Community Development Project Supervisor with the Town of Islip, NY. Professor LoPiccolo received her undergraduate and professional degree with honors from Dublin Institute of Technology - Bolton Street College of Technology and Trinity College, The University of Dublin, Ireland, and her post-professional degree in Architecture Urban Regional Design from New York Institute of Technology. Subsequently, Professor LoPiccolo received a Postgraduate Diploma in Building Construction Management from New York University where she was awarded the Excellence in Academic Achievement Award. She has also recently earned Passive House Designer Certification from the Passivhaus Institut, Germany. Professor LoPiccolo is a member of committees and groups at Farmingdale State College, including being the Chair of the Calendar Committee (a Standing Committee), and an active member of: the Green Building Institute, Smart Grid Committee, Leadership, Governance and Administration Middles States Working Group Sub-Committee, Academic Working Group Committee for the college's Centennial Celebration, and an Orientation Faculty Leader. Professor LoPiccolo has received a Presidential Commendation for her Calendar Committee work. Being the Outreach Chair in her department, Professor LoPiccolo and has incorporated service learning into her Construction Design course since she started at Farmingdale State College. Off campus, Professor LoPiccolo has completed a 3 year term as the Secretary and Treasurer of American Society of Engineering Education (ASEE) Middle Atlantic Section and was recently elected as Chair Elect of this section. In addition to her numerous presentations and publications on her research in teaching sustainable construction methods and in service learning, Professor LoPiccolo has New York State Building and Energy Code certifications, Passive House consultant training, International Code Council (ICC) certifications Green Building, and Residential Energy, and Building Performance Institute (BPI) certifications Building Analyst Professional and Building Envelope Professional. Professor LoPiccolo has researched and integrated sustainable construction techniques, service learning, student-built physical models, Autodesk Revit Architecture and field trips into her courses and she was as awarded a Title III Students First grant to introduce freshmen students to sustainable construction methods including Passive House design. Professor LoPiccolo teaches Materials and Methods of Construction I (CON 161), Graphics I (CON 111), Graphics II (CON 121), Mechanical, Electrical, Plumbing and Energy Systems (ARC 263), Construction Design (ARC 272), Site Design and Construction (ARC 364), Construction Project Management and Scheduling (CON 401W), Advanced Project Planning and Scheduling (CON 406). Professor LoPiccolo brings private and public sector architectural work experience; architectural teaching experience; service on and off campus; sustainable construction knowledge, scholarship and course integration; service learning course integration; and a commitment to continual improvement to the Department of Architecture and Construction Management at Farmingdale State College, SUNY. 


\title{
Teaching and Learning through Telling Faculty Work Experience Stories: A Preliminary Study
}

\begin{abstract}
Students who are engaged in their coursework learn and retain more knowledge than those who are not engaged in their coursework. There are numerous pedagogical methods used to actively engage students in their learning such as: projects in and out of the classroom, laboratory work, jigsaw learning, service learning, field trips, and research. Other methods of classroom instruction also engage students in learning by simpler more subtle means, such as: randomly selecting students during a lecture to answer questions or give their opinion on a topic, studentproduced journals, peer review, and through faculty sharing stories related to the course topics from their own work experience. The goal of this paper is to examine the use of the latter. Does teaching with the incorporation of course topic-related stories improve student learning? TED (Technology, Entertainment and Design) Talk speakers use stories to engage listeners effectively, so why not tell stories to engage students in a 3-hour-long lecture? Two groups of freshmen students were pre-tested in a course topic, then given the same lecture on the course topic with one exception. In one group, the faculty member wove stories from their own work experience, or that of others, into teaching the course topic throughout the lecture, and in the other group, the faculty refrained from telling these course-related stories. Both groups were then given the same post-test for the same time duration. The results of this preliminary study will provide faculty with an understanding of the relative benefit of engaging students through work experience storytelling.
\end{abstract}

Background

Here is the back story. The Farmingdale State College Materials and Methods of Construction I (CON 161) course is required for freshman in both the Architecture Engineering Technology and Construction Management Engineering Technology programs. It is a 3 hour, once a week foundation lecture course that introduces students to: the construction industry, soils, foundations, heavy timber, light wood framing, masonry, and steel frame construction. The vast majority of students in this course are male commuter students who also work part-time in jobs that are in or outside of the construction industry. The author has taught numerous sections of this course over the past 8 years and has tested a variety of project-based teaching methods in this course with the goal of increasing the engagement of students in learning. In 2011, the author was awarded a campus Student First Grant as part of a Title III initiative to improve student engagement in this course through a field trip to an award-winning, sustainable building; 3-D student-built physical models; and jigsaw learning. The author has also worked in the field of architecture and construction management for over 16 years and readily shares course topicrelated stories from personal experience with students. Over time, the author noticed that with each professionally related story, students would become more engaged in class. They would start to lean forward in their desks, their faces would light up with interest, and they would ask more questions. Students appeared to enjoy learning how their course content could be used in the field, how problems were solved and the lesson learned via the story. They appeared to be 
more engaged when they heard a course-related story. Was theory becoming real to students through sharing a professional experience story with them? Perhaps the stories would increase their learning retention of the related topics? The author became curious if students retained more subject knowledge through hearing their professional experiences that related to their coursework. TED (Technology, Entertainment and Design) Talk speakers use stories to engage listeners effectively, so why not tell TED-type stories to engage students in a 3-hour-long lecture? The author wanted to find out what effect a professor relating professional experience would have on student learning retention in comparison to the same lecture given without these real life stories. The goal of this paper is to investigate the background of storytelling in education and show its effect on student retention of related course material by comparing two sections of a first-semester freshmen course. The results of this preliminary study will provide faculty with an understanding of the relative benefit of engaging students through work experience storytelling.

Storytelling in Education:

Telling stories is the oldest form of teaching and learning. ${ }^{1}$ It has been a method of educating from pre-historic times. One generation to the next has told stories to educate and entertain since humans left Africa 200,000 years ago ${ }^{1}$. Children in K-12 learn about the world through first hearing stories, then reading stories, writing stories and telling stories. In college, students may take a writing intensive course in which they research a course topic or case study ${ }^{2}$ and present their findings as an oral story to their peers. They learn by teaching others through stories. There are many different methods of faculty storytelling in the classroom. A teacher may relay a story they have read or heard to emphasize a point, encourage students to tell their own experiences that relate to a lecture subject, create a hypothetical story to encourage deeper thinking of a concept or share their own work experience, if they have any, that is related to a course topic.

Architecture and engineering professors who have worked as architects/engineers prior to or while teaching have an advantage. They bring a wealth of real-world knowledge to the classroom that they share through relating personal experiences related to each course topic and concept. This is the same for other licensed professionals who become professors, such as doctors, dentists and lawyers. They share their professional experience with their students as a pedagogical tool. Students enter these professional programs expecting to learn from professors who have real world experience in their area(s) of expertise. However, many engineering faculty have not worked outside of academia and therefore do not have any real world work experience to share. This is a major problem as it creates a disconnect between what they can teach and how it will connect to the main reason why the majority of their students are in college in the first place - to be prepared for a career outside of academia. Therefore, engineering faculty without professional experience outside of academia who plan to use storytelling in their courses, must make an extra effort to find stories that are relevant to their course topics. ${ }^{3}$ They may borrow course-related stories from colleagues who do or have worked in the field, from professional publications, and from professional society meetings. However, answering student questions 
about these borrowed stories may be a problem that cannot be easily solved. It is often difficult to answer questions in depth without having experienced the story first-hand.

Why use storytelling in the college classroom?

Oral storytelling has been integral to teaching and learning because it:

1. Relays a human experience through which a student can place themselves into the story and learn from its outcome - when we listen to a story that intertwines a new topic into a relatable story, it is human nature to place yourself into the role of the storyteller.

"After nourishment, shelter and companionship, stories are the thing we need most in the world." - Philip Pullman

2. Brings meaning to a theoretical concept by telling a story of how it was implemented in a


future careers by hearing how their professor solved a problem that arose with the material being taught.

3. Offers variety to the methods that can be used to illustrate a point in a lecture - the lecture used in this test is 3-hours-long once per week class and telling a course-related story changes the pace of the lecture and an opportunity to show how the topic is real.

4. Engages students' interest - stories increase students' attention to the course topic and make it easier to understand.

5. May make the teacher more approachable - students learn more about their professor's professional work outside of the classroom through the use of professional work experiences that are relevant to the course topic. Per Karanian et al, "The nature of personal interaction appears to have an empowering symbiotic energy when guided by a strong connection among members."

6. May offer students an opportunity to comment on each course-related story.

7. May offer students an opportunity to share their own similar work experiences, if they have any.

How to Tell Course-Related Stories

The following is a list of items to keep in mind when preparing your lecture using topic-related stories:

1. Relevant - stories must be related to the topic of the lecture and have a purpose of informing the students about a situation they may face in their future profession. ${ }^{2}$

2. Short - stories must not be lengthy or rambling. If they are, students will quickly lose interest. Per "Talk Like Ted" 6 author Gallo, the maximum length of a story should be 18 
minutes: "TED curator Chris Anderson explained it best: It [18 minutes] is long enough to be serious and short enough to hold people's attention."

3. Structured - course-related stories must have a beginning, middle and end.

4. Conversational - "conversational storytelling is the foundation for effortless engagement."7

5. Ask for student input ${ }^{8}$ - ask students questions about the story, such as what would they have done if they were you, now that they understand the lecture topic being discussed.

6. Movement around the classroom - similar to giving an engaging lecture, try not to stand in one place. Walk around the classroom and look at different students as you tell the story. This will keep all students engaged, even those who may not be fully engaged at the start of the story.

Methodology

In fall 2016, the author taught three different courses and a second section of one of these courses - Materials and Methods of Construction I (CON 161). This course is a freshmen introductory course that runs as one 3-hour class once a week, and it covers a wide range of material including: the members of the construction team, zoning, the building code, soils, foundations, wood, heavy timber construction, light wood frame construction, masonry and steel frame. Each of the two sections of this course had 27 students. Both groups were pre-tested in the same course topics covered in one class, then they were given the same lecture on the course topics with one exception. In one group, the author wove stories from their own work experience related to each course topic covered throughout the lecture, while in the other group, the author refrained from telling course-related stories. While performing this study, the author was mindful to relate the lecture portions of the class with the same enthusiasm and did not test the students on the story content. The topics of this introductory class were: the roles of members of the construction team, construction documents, zoning and the building code. The stories told to the "story" group included:

1. A story about being an architect in contract with an owner, working with a construction manager and several contractors (instead of one general contractor) on a Wicks Law project, the problems that arose (scheduling conflicts, errors made by one contractor who blamed others, and change orders) and how the project finished behind schedule because of these problems.

2. A construction document story about submitting revised drawings and specifications to a building department and how these construction documents went to the bottom of the "initial review" pile delaying the permitting process until the architect discovered that the drawings were not on the "revised" pile of drawings. 
3. A zoning story about a building that was constructed one foot over the setback line in error, how legally the encroaching outer wall could have been required to be moved back (causing major changes to the roof structure amongst other building components), and how the owner had to apply to Zoning Board of Appeals for a variance to legally keep the wall encroaching over the setback line.

4. A story about a building code issue due to the removal of a concrete outdoor mezzanine that exposed an unforeseen corroded steel ring beam that caused the project to be delayed and over budget. How the mezzanine had to be replaced "in-kind" per the New York State Building Code instead of the more logical open grate powder coated metal version that per code would have required a complete egress stair enclosure adding costs beyond the budget.

Following the lecture both groups were then given the same post-test (see below) for the same time duration, and also a qualitative survey (listed in the Results section).

Pre- and Post-Test Questions (26 points maximum, each correct answer is 1 point):

1. Who are the three traditional principal team members involved in the creation of a new building? What are their respective roles?

2. Construction documents are comprised of two main items - what are they?

3. Why are construction documents used?

4. List two (2) types of subjects covered by zoning ordinances:

5. List two (2) types of subjects covered by building codes:

6. In what units is fire resistance measured?

7. True (T) /False (F) Questions: Answer $\mathrm{T}$ for True and $\mathrm{F}$ for False

a. A building code contains parking lot requirements.

b. With the exception of some $\mathrm{H}$ Hazardous occupancies, there is no limit in the building code on the height to which a Type 1A building can be built.

c. First cost and life-cycle cost are usually the same.

d. A single-family detached dwelling may be built of wood without any fire protection. In general, it costs more to make a building more resistant to fire.

e. A general contractor provides design and construction services to a building owner.

f. A subcontractor is a construction entity that contracts directly with the owner to provide specialized construction services. 
g. In design/build construction, the design team and the construction team are part of the same entity.

8. A client has asked you to design a clothing store (Occupancy Group M) of protected platform frame, Type IIIB construction (non-combustible exterior walls and interior building elements of any material permitted by the code). The building will not be fully sprinklered. (a building code chart as given to students for this question, omitted here)

a. How tall in feet and stories can this building be?

b. If built to its maximum permitted height, what is the maximum allowable area for all floors combined?

9. What is the maximum height in stories and feet, for a reinforced concrete office tower (occupancy group B) of Type 1A construction? stories, feet

Results

The following are the quantitative results from the pre-test and post-test for each group, using the title "Stories" for the group who were told stories related to the lecture topics and "No Stories" for the group who were given the same lecture but without stories. The grade for each student in each group and the average grade per group is given for the pre-test and the post-test. The total difference and the average difference is also given and statistics are provided:

Stories

\begin{tabular}{|r|r|r|r|}
\hline $\begin{array}{c}\text { Group 1 } \\
\text { Student }\end{array}$ & $\begin{array}{c}\text { Pre-Test } \\
\text { out of } \\
26 \text { max }\end{array}$ & $\begin{array}{c}\text { Post-Test } \\
\text { STORIES } \\
26 \text { max }\end{array}$ & \\
\hline 12 & 4 & 12 & Difference \\
\hline 5 & 11 & 15 & 8 \\
\hline 11 & 9 & 17 & 4 \\
\hline 22 & 9 & 17 & 8 \\
\hline 16 & 12 & 18 & 8 \\
\hline 19 & 11 & 18 & 6 \\
\hline 21 & 7 & 18 & 11 \\
\hline 9 & 4 & 19 & 15 \\
\hline 1 & 7 & 20 & 13 \\
\hline 4 & 10 & 20 & 10 \\
\hline 6 & 11 & 20 & 9 \\
\hline 18 & 5 & 20 & 15 \\
\hline & & & \\
\hline
\end{tabular}

\section{No Stories}

\begin{tabular}{|r|r|r|r|}
\hline $\begin{array}{c}\text { Group 2 } \\
\text { Student }\end{array}$ & $\begin{array}{c}\text { Pre- } \\
\text { Test } \\
\text { out of } \\
26 \text { max }\end{array}$ & $\begin{array}{c}\text { Post-Test } \\
\text { NO } \\
\text { STORIES } \\
26 \text { max }\end{array}$ & Difference \\
\hline 14 & 6 & 8 & 2 \\
\hline 18 & 5 & 9 & 4 \\
\hline 11 & 4 & 10 & 6 \\
\hline 12 & 4 & 10 & 6 \\
\hline 16 & 5 & 10 & 5 \\
\hline 27 & 6 & 10 & 4 \\
\hline 7 & 5 & 11 & 6 \\
\hline 13 & 5 & 11 & 6 \\
\hline 1 & 4 & 13 & 9 \\
\hline 2 & 9 & 13 & 4 \\
\hline 24 & 8 & 13 & 5 \\
\hline 8 & 7 & 14 & 7 \\
\hline
\end{tabular}




\begin{tabular}{|r|r|r|r|}
25 & 13 & 20 & 7 \\
\hline 26 & 12 & 20 & 8 \\
\hline 3 & 7 & 21 & 14 \\
\hline 10 & 10 & 21 & 11 \\
\hline 27 & 7 & 21 & 14 \\
\hline 2 & 7 & 22 & 15 \\
\hline 17 & 15 & 22 & 7 \\
\hline 23 & 7 & 22 & 15 \\
\hline 7 & 18 & 23 & 5 \\
\hline 14 & 4 & 23 & 19 \\
\hline 15 & 14 & 23 & 9 \\
\hline 20 & 19 & 23 & 4 \\
\hline 8 & 4 & 24 & 20 \\
\hline 13 & 15 & 24 & 9 \\
\hline 24 & 8 & 24 & 16 \\
\hline Average & 9.63 & 20.26 & \\
\hline
\end{tabular}

Total

Diff

287

\begin{tabular}{|r|r|r|r|}
\hline 22 & 11 & 14 & 3 \\
\hline 6 & 8 & 15 & 7 \\
\hline 17 & 5 & 15 & 10 \\
\hline 21 & 6 & 15 & 9 \\
\hline 23 & 5 & 15 & 10 \\
\hline 9 & 6 & 16 & 10 \\
\hline 19 & 7 & 16 & 9 \\
\hline 3 & 9 & 17 & 8 \\
\hline 5 & 9 & 17 & 8 \\
\hline 15 & 10 & 17 & 7 \\
\hline 25 & 4 & 17 & 13 \\
\hline 10 & 6 & 19 & 13 \\
\hline 26 & 6 & 19 & 13 \\
\hline 4 & 7 & 21 & 14 \\
\hline 20 & 10 & 24 & 14 \\
\hline Average & 6.56 & 14.41 &
\end{tabular}

Total

Diff

Av.

Av.

Diff.

10.63

Diff.

Stories

No Stories

t-Test: Two-Sample Assuming Unequal Variances

\begin{tabular}{|l|r|r|}
\hline \multicolumn{1}{l|}{} & \multicolumn{1}{c}{ Group } & Group \\
\hline Mean & 10.63 & \multicolumn{1}{c|}{7.85} \\
\hline Variance & 19.55 & 11.82 \\
\hline Observations & 27 & 27 \\
\hline Hypothesized Mean & \multicolumn{2}{|c|}{0} \\
Difference & \multicolumn{2}{c|}{0} \\
\hline df & \multicolumn{2}{|c|}{49} \\
\hline $\mathrm{t}$ Stat & \multicolumn{2}{|c|}{2.58} \\
\hline $\mathrm{P}(\mathrm{T}<=\mathrm{t})$ one-tail & \multicolumn{2}{|c|}{0.01} \\
\hline $\mathrm{t}$ Critical one-tail & \multicolumn{2}{|c|}{1.68} \\
\hline
\end{tabular}

The following are the qualitative results from a survey of six questions that was given to both the course-related story group and the group without stories following their post-tests:

Interestingly, $100 \%$ of both groups answered "Yes" to the following four questions of the six qualitative questions asked:

1. Do stories related to the class topics get your attention? 
2. Do stories related to the class topics make the subject easier to understand?

3. Do stories related to the class topics make the information presented more realistic?

4. If a teacher shares professional work experiences that are related to the class topic(s) do you feel that the class atmosphere is more welcoming?

The remaining two qualitative questions with the breakdown of their answers are as follows:

5. If a teacher shares professional work experiences that are related to the class topic(s), would you be more likely to comment on your thoughts about the story? The survey showed that $93 \%$ of the course-related story group answered "Yes" (7\% answered "No"), and $88 \%$ of the group without stories answered "Yes" (12\% answered "No").

6. If a teacher shares professional work experiences that are related to the class topic(s), and you have your own work experiences with the class topic would you feel comfortable sharing them with the class? The survey showed that $93 \%$ of the course-related story group answered "Yes" (7\% answered "No"), and $88 \%$ of the group without stories answered "Yes" (12\% answered "No").

\section{Discussion}

In this preliminary study, it was found that telling course-related professional work experience stories had a statistically significant effect regarding improving students' learning retention compared to students who heard the same lecture without these stories. Students who were engaged in the lecture through stories retained an increased average of 10.63 points out of 26 maximum from pre-test to post-test, compared to the group without stories who retained an average of 7.85 points out of 26 from pre-test to post-test. Therefore, the group with the courserelated stories retained $26.15 \%$ more course material than their peers who did not hear the course-related stories. Students in both the related-course story section and the group without stories both agreed that stories increased their attention, made the subject easier to understand, make the class topics more realistic and created a more welcoming atmosphere. The majority of both groups also agreed that course-related stories would encourage them to comment on their thoughts about the story and share their own experiences with the topic if they had any similar work experience.

\section{Conclusion}

The use of course-related stories from faculty experience has been shown to increase student retention of learning in this study and the use of course-related stories sparks student attention, makes the subject matter easier to understand and more realistic, and their professor more approachable. These stories are also likely to encourage student participation in class. Our story ends with a recommendation to use your professional course-related stories in your courses even through a plan for future study with a larger sample size is warranted to further this investigation. 


\section{References}

${ }^{1}$ M. Friday, "Why Storytelling in the Classroom Matters, Edutopia," 11 July 2014. [Online]. Available: https://www.edutopia.org/blog/storytelling-in-the-classroom-matters-matthew-fridayFriday. [Accessed 30 January 2017].

2 Chawla, R. (2005, June), Use Of News Stories As Case Studies For Teaching Engineering Analysis Paper presented at 2005 Annual Conference, Portland, Oregon. https://peer.asee.org/15051

${ }^{3}$ Olwi, I. A. (2014, June), Story Telling as an Effective Mean for Stimulating Students' Passion in Engineering ClassesPaper presented at 2014 ASEE International Forum, Indianapolis, Indiana. https://peer.asee.org/17199

${ }^{4}$ Chesney, D. (2006, June), Big Fish: The Lost Art Of Story Telling In The Engineering Classroom Paper presented at 2006 Annual Conference \& Exposition, Chicago, Illinois. https://peer.asee.org/12

${ }^{5}$ Karanian, B., \& Kress, G., \& Sadler, J. (2009, June), Telling Design Stories For Engineering Design Entrepreneurship Paper presented at 2009 Annual Conference \& Exposition, Austin, Texas. https://peer.asee.org/5784

${ }^{6}$ Gallo, C., (2014, March), Talk Like Ted The 9 Public-Speaking Secrets of the World's Top Minds, (P150), St. Martins Press

${ }^{7}$ Karanian, B. A., \& Eskandari, M., \& Taajamaa, V. (2016, June), Conversational Storytelling: Classroom Teaching through Story Parallels Entrepreneurial Need for Engagement Paper presented at 2016 ASEE Annual Conference \& Exposition, New Orleans, Louisiana. 10.18260/p.26587

${ }^{8}$ Chesney, D. (2007, June), Big Fish Ii: The Lost Science Of Story Telling In The Engineering Classroom Paper presented at 2007 Annual Conference \& Exposition, Honolulu, Hawaii. https://peer.asee.org/1741 